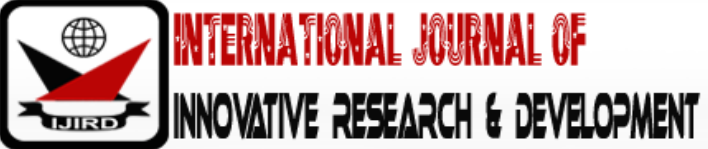

ISSN 2278 - 0211 (Online)

\section{Impacting Factors on Student Volunteers at the Academic Library}

\author{
Huynh Thi Trang \\ Senior Lecturer, Department of Library and Information Management, \\ Can Tho University, Vietnam \\ Tran Xuan Bich Ngoc \\ Graduated Student, Department of Library and Information Management, \\ Can Tho University, Vietnam
}

\begin{abstract}
:
This study is aimed at identifying the impacting factors on student volunteers at an academic library in the Mekong Delta, Vietnam. Underpinned by the conceptual framework of volunteer and volunteering defined by Wilson (2000),the study was carried out using quantitative methods. Through emails and in-person meetings, a survey questionnaire was delivered to all volunteers in the LRC. There were 100 responses which reach the ideal samples as noted by Hair and his colleagues (2009). Data collected in this study were analyzed using SPSS with Cronbach's Alpha, Exploratory Factor Analysis and multivariate regression to determine factors influencing students' decisions and their impacting level to volunteer at the library. Research findings indicate two factors influencing on student volunteering are experiences and relationships. An evaluation research on quality of student volunteering will be proposed to further research, so as to get further information about how productively the student volunteers can support their library. This study fills the gap by examining the impacting factors on volunteering that benefits the LRC and volunteering students. As a result of this influence, students are expected to know more about benefits and responsibilities of volunteering at the library, thereby obtaining greater experience, communication ability and confidence in their future work and life. This research contributes to literature about impacting factors on the student volunteers at the academic library in an Asian country context, which has not been discussed so far. It also provides possible solutions to attract and retain the student force for the library functions.
\end{abstract}

Keywords: Academic library, impacting factors, motivation, student volunteers, volunteers, volunteering, workforce

\section{Introduction}

Lack of human resources to improve or maintain library services becomes a big challenge for most libraries in the world including those in Vietnam. To deal with this restraint, libraries have initiated volunteer programs to recruit outsourcing forces. For the academic libraries in Vietnam, students and librarianship students have been considered to provide and maintain the library functions.

Launched with 57 full-time staff at the early establishment stage in 2006, Can Tho University Learning Resource Center (LRC) currently own sonly 35 ones. Because of this shrinking workforce, students from different training disciplines including librarianship students have been encouraged to participate in volunteer programs at this library. However, after six years of operating these programs, the LRC has not promoted this student force effectively. In particular, a large number of volunteers only participated in a short time and the remaining ones involved in the long term in face-time spirits. Therefore, it necessitates research into seeking solutions to encourage students to devote their time, efforts, and energy to complete such tasks at the library. Furthermore, although there are lots of books and research on how to attract and sustain volunteers, no research has been examined the factors influencing student participation in volunteering at the LRC. This study therefore fills that gap by examining the impacting factors on volunteering that benefits the LRC and volunteering students with regard to the ways to enrich its human resources in fulfilling the library functions. As a result of this influence, students are expected to know more about benefits and responsibilities of volunteering at the library, there by obtaining greater experience, communication ability and confidence in their future work and life.

\section{Literature Review}

\subsection{Conceptual Framework}

There are several definitions of volunteering and volunteer inthe literature. According toWilson (2000), volunteering is generally considered as an altruistic activity where an individual or group provides services for no 
financial gain to benefit another person, group or organization. Volunteering is a significant endeavour. In particular, Hardill and Baines (2007) state that volunteering is a way of developing skills and increasing ability to work. In addition, McCabe, White and Obst (2007) claim that volunteering necessitates maintaining, developing and expanding skills for students' future work. In general, volunteering opens up many opportunities for its participants, such as developing skills, improving their ability to work and raising social awareness (Holdsworth \& Brewis, 2014). Similarly, AmeriCorps \& Senior Corps (2019) indicate that volunteering is aimed at preparing today's students for tomorrow's jobs, connecting returning veterans to jobs, supporting seniors to live independently, making college more accessible and affordable, and helping people rebuild their lives following some potential disasters.

Drawing on the seconceptualizations of volunteering,Farlex (2019) definesa volunteer is a person who does some act or enters into a transaction without being under any legal obligation to do so and without being promised any remuneration for his/her services. In Canada, most people whose age from15 to 19 participated in volunteering to improve their employment opportunities (Hall et al., 2009). In America, volunteers are persons of16 and older, serving in an organization without pay at any point during a 12-month-period (AmeriCorps \& Senior Corps 2019).In library environment, Holt and Holt (2014) categorise volunteers into various types. They are volunteers lending experience to collections, volunteers providing literacy instruction, volunteers providing technology instruction, volunteers providing life help, volunteers keeping the library functioning, librarian volunteers helping other librarians, volunteer special project helping change the library's future.

From the above definitions, it is understandable that library volunteers are people who voluntarily devote themselves to library services as well as library projects and do not require any payment. In other words, the main point of the library volunteer concept is to do the library work voluntarily and not receive remuneration. This underpinning concept helps to build the questionnaire to find answers that meet the intended research objectives.

The researchis to identify the impacting factors on volunteering at the LRC to help this library overcome the shortage of human resources andkeep the library functioning. The specific objectives are:

- To evaluate student volunteering at the LRC;

- To identify the impacting factors on volunteering at the LRC;

- To provide possible solutions to attract more and long-term volunteering students at the LRC.

In order to fulfil these objectives, three research questions are raised as follows:

- $\left(\mathrm{Q}_{1}\right)$ To what extent do students volunteer to work at the LRC?

- $\left(\mathrm{Q}_{2}\right)$ What factors influence student volunteers at the LRC?

- $\left(\mathrm{Q}_{3}\right)$ In what ways canthe LRC attract volunteering students?

\subsection{Related Research}

\subsubsection{Motivations to be Volunteers}

Volunteering is an important and humanistic deed that each organization may get individuals involved. Motivation to volunteer to do something is widely discussed in the literature. Clary and his colleagues (1998) identify six types of motivation for volunteering. They include developing and enhancing one's career (career); improving and enriching personal development (self-esteem); being consistent with the norms, or set norms for, meaningful to others (society); getting rid of negative emotions (protection); learning new skills and proper practice (knowledge); and denoting values related to altruistic beliefs (values). In other words, the key motivation to be volunteers is an opportunity to gain workrelated experience, skills and certifications for their studies and future jobs(Eley, 2002).

More succinct than the above researchers' indications, Riemer and colleagues(2004) address four basic motivation elements for voluntary participation in youth-oriented programs. They include friends' and family members' participation, love of their own activities, their desire to create something better, and awareness of their own responsibilities. In the meanwhile, a survey of volunteering in the United Kingdom shows that motivation to volunteer include 19 categories besides personal, free time and religious interests. Similarly, creating opportunities to work and gain experiences on direct customer service interaction, inventory control, time management and interviewing techniques are volunteering motivation, as noted by Bernier (2009). In addition, Shye (2010) confirms motivations are to develop friendship, enhance the feeling about society or community, contribute to improving social value, self-characterize and express their beliefs.

Many young people's first experiences in volunteering are from the programs at the school and teachers have important roles in inspiring their students of volunteering. For instance, Holdsworth (2010) carried out a research with 3,083 students from six different universities across the UK and came up with three main driving forces affecting volunteers. They are employment, skills and increasing learning and personal values. According to Hoang Lam (2012), motivation for volunteering comes from love for human/ human love. In particular, it is from love for less fortunate people such as disabilities, homeless, poor people, and children living in remote areas. Recently, Lehn (2016) indicates three top motivations of the volunteers, namely passion for the cause, opportunity to meet people, and skills needed to share. Similarly, Ha Linh (2017) claims that the motivation for volunteering comes from the impression of the previous volunteers and the passion to devote themselves to the community. Thus, the motivations to participate are from the desire to share and help the disabled and the homeless to become useful citizens for society.

\subsubsection{Impacting Factors on Volunteering}

Desire and motivation to volunteer may be affected by different factors. In particular, two factors that motivate young people to volunteer are learning new skills or raise their values at work (Low et al., 2007). Volunteering can be 
affected by personal satisfaction, academic achievement, desire for leadership and training skills, and future job. Individuals can also build self-esteem, gain valuable knowledge, develop themselves and discover new talents in volunteering. According to Roberts (2016), two impacting factors to volunteers are individual's relationships and wouldbe volunteers. In terms of individual's relationships with the community, it can be known as "a desire to actively contribute to the community, a wish to make a difference in the lives of others, and a requirement to earn credit, such as for high school or college courses or to perform community service required by courts or social service agencies. Would-be volunteers are the ones who feel useful, develop new skills, increase chances for employment, in the library or elsewhere, share skills developed through employment or hobbies, especially in retirement, be on the "inside" as one who is admitted to the inner workings of the library, and meet others and make new friends" (p. 89).

Individual's desire and awareness motivate students to participate into volunteer programs at the library. Retaining volunteers is the practitioners' responsibilities. In fact, practitioners must invest time and commitment in developing and supervising volunteers (Forrest 2012). In addition, Holt and Holt (2014) indicate that practitioners have to spend planning time and work with library staff to produce a successful volunteer program in order to avoid volunteers' discontent and complaints as well as keep them stay longer with the library. Similarly,Berroteran (2016) states that it is flexibility and creativity of volunteer program to attract and retain talented, enthusiastic and productive volunteers. Indeed, the volunteer program has to elicit clear job descriptions, duties and responsibilities for the willingness helpers of the library. Thus, interpersonal, operational and structural in volunteer program are three innovative categories to deal with challenges and sustaining of the volunteers (Colibaba, Skinner, and Furgal 2019).

\subsubsection{Requirements to be Library Volunteers}

Required competents to be library volunteers are listed in volunteer programs. In San Antonio Public Library (n.y), volunteers have to bein the age 14 or older, mature, reliable personality, ready to serve customers, flexible, responsible for assigned tasks, comply with library policies and functions. In the meanwhile, Fairview Branch library favours volunteers who can support readers from high school students to seniors and should be native English speakers. In addition, volunteers aged 18 and over are required to collect fingerprints as part of a background check for individuals working with children (US Fed News Service, 2006). Similarly, the Seattle Public Library (2018) favours adult volunteers who are at least 18 years old. Furthermore, 6 month-working experience and good at tutor for the library users are selection criteria for volunteers at the Central Library, the Broadview and Rainier Beach branches. Moreover, for the Public Library Association, volunteers must be its members in good standing for the duration of their appointment(Public Library Association 2019).

In Vietnam, volunteers of a charity program have to show their serious work, carefulness, concentration and dedication and pass three rounds of interviews (Nguyen, 2016). In the meanwhile, volunteers for the Green Library project are considered among students inside Hanoi capital, enthusiastic, responsible of the community, creative, and ability of designing as well as making craft products (Mario, 2016). Similarly, Three Cups of Tea Library project of the Center for Community Consultation, Research and Development (2016) recruit students from universities and colleges in Hanoi, good at reading and promoting reading culture, enthusiasm, and responsibility for the assigned work. In addition, priority is given to candidates with good English speaking and writing as well as relevant social activities experience. Volunteers in the University of Economics and Law Library (2017) are those with various skills and qualities such as good morality, honesty and enthusiasm, good communication, team-work, working under high pressure, proficiency in ICT, English, internet usage, and open source systems.

\subsubsection{Responsibilities of Library Volunteers}

Volunteers are required to complete their given tasks. They need to have full participation in meetings, that is, their names will be removed from volunteering lists if they are absent from meetings more than twice, follow library rules and present in enthusiastic or positive attitudes toward a particular activity (Do, 2016).Quite different from this library, another academic library in Vietnam (2017) demands that volunteers should perform their tasks according to a registered schedule under the supervision of the librarian.

\subsubsection{Duties of Library Volunteers}

In libraries, volunteers are asked to involve in some activities as supporters or facilitators. For example, to respond to budget constraint and manpower of the Kingston Public Library, volunteers are required to maintain and support certain services such as bringing books to users, planting flowers around the library, watering plants and taking care of the library property (McDonald, 1996). At the Tualatin Library in Washington, D.C. volunteers are asked to prepare materials for the library program. They involve stapling, shelving and making other manual tips (US Fed News Service, 2009).Moreover, volunteers also participate in selling books and donating money to build libraries in special fundraising projects. In an academic library, volunteers have to participate in social activities, namely supporting high school exams, blood donation, Earth Hour, and Green Sunday (Hoang, 2016).

\subsubsection{Benefits to be Library Volunteers}

As library volunteers, students will meet more people, get different experiences, feel happy to help others, get valuable information from the library (The San Antonio Public Library, ny). At the Fairfield County District Library (ny), young people are interested in working in a fun environment, earning community hours and promoting their jobs and college programs that encourage volunteering at the library during the summer. Similarly, in the Toronto Public Library (n.y) youth ages 13-19 are volunteers through youth counselling groups at their local libraries and earn the necessary 
community hours for high school. Besides, volunteers are adults and help children in primary school. They can improve your reading and learning skills, sometimes also supporting homework. The Seattle Public Library (2018) introduced volunteer work at the library as a way to provide meaningful services to the community and to understand other people, sharing their skills and talents and gain valuable experience from volunteering, increase their chances of participating in service learning activities and earn community service hours for high school or college. There are also volunteering opportunities for high school students aged 14 and over and living in Seattle. Working in a library can help them develop important skills for school, work and life, such as critical thinking, problem solving, communication and working with others to earn hours at community services to fulfil high school requirements, as well as acquire leadership and project management skills. This volunteer experience will help them apply into university, meet many wonderful people and become friends.

In Vietnam, Nguyen Tien Dung (2013) shares benefits of volunteering at Gia Lai Teacher's College Library are priority to borrow many books for many daysand more Internet access hours. Most of all, they have the opportunities to interact with friends in the school, easily access to library collections. As volunteers, they can help library in preservation of valuable books and increase their effective services. The Green Library Project creates chances for volunteers working with dynamic and professional people. Young people will be more confident in volunteering, knowledgeable of new places, making new friends, improving teamwork and design skills and receiving certificates of participation in the project of Hanoi Young Inspirers (Mario, 2016).

Volunteers of the Three Cups of Tea Library project will enjoy many benefits such as working, learning and experiencing in a friendly and professional working environment, reading diversified books that contribute to improving their foreign language ability as $80 \%$ of library books are written in English, receiving incentives when participating in events, training programs of the Center, having more opportunities to interact with local and international friends and receiving a certificate of volunteering after six months working at the library.At An Giang University Library, a group of volunteers has many benefits such as being granted VIP library membership cards and training points (depending on the level of contribution), participating in information search skills training classes, believing and giving priority to participating in seminars and conferences organized by the library, being rewarded when making positive contributions to the library. Especially, library volunteering alumni will be given priority to borrow books in the library (Do, 2016). These benefits are also similar to volunteers at Ba Ria - Vung Tau University Library (2017). It is to prioritize borrowing documents with more lending duration. In LRC, volunteers are allowed to borrow up to five documents for a month and are renewed for a week if the book is not in high demand (LRC, 2018).

\section{Research Methodology}

The study was carried out using quantitative methods. Through emails and in person meetings, asurvey questionnaire was delivered/ sent to all volunteers in the LRC regardless of gender, age, academic year, major or place to live. The survey includes two parts. Part One consists of demographic questions. Part Two includes fivegroups of questionswith44 observed variables of affecting factors on volunteering. Final question was the open-ended one to collect volunteers' comments and opinions of how to attract more student volunteers to the library.

The questionnaire was designed according to five-point Likert scale. It took participants approximatelyten minutes to complete the questionnaire. With the printed questionnaire distributed at the LRC, volunteers were explained with the necessary information. Volunteers were informedif they answered online, not to fill in the printed versionto avoid the overlapping of the data. Under this setting, volunteers did not miss any item when responding to the questions from online survey. Before the official survey were conducted, a pilot was administered to 20 volunteers via emailsin order to check the relevance, reliability, response time, structure, and additional comments.

Quantitative data was analysedusing SPSS software. This software tested the reliability of the questionnaire and each group of the affecting factors by the Cronbach's Alpha confidence. The Exploratory Factor Analysis (EFA) function of the software was used to determine the groups of factors influencing on students' decision to volunteer at the library. The study also used multivariate regression method to determine the data with regard to the strongest to the lowest factors. Data collected from open-ended question were analysed using categories in Microsoft word. This analysis allows for identifying what factors could motivate volunteers and figuring outsuggestions to the LRC to attract student volunteers.

\section{Findings}

\subsection{Student Volunteers at the LRC}

Within six years (2013 - 2018) of operating the volunteer programs, the LRC attracted 374 students from 15 schools and colleges of the university. Three of these schools and colleges marked the top of student volunteers. They are the College of Economics, College of Agriculture and School of Social Sciences and Humanities with 73,73 and 65 volunteers respectively. In the meanwhile, the College of Rural Development score the least with only two students. There is no volunteer from School of Graduate and School of Pre-University. In addition, there is a big difference in the number of student volunteers by gender of six academic classes (Courses39-44). Data in Figure 1 illustrates that majority of volunteers are female $(n=280)$ with three times higher than male $(n=94)$. Furthermore, volunteers inCourse40 reach the highest one of all academic classes with 106 females and 27 males. There are no female volunteers belonging toCourse39. In addition, the highest number of male volunteers inCourse41 $(n=38)$ and the lowest one is inCourse44 with only one male volunteer. 


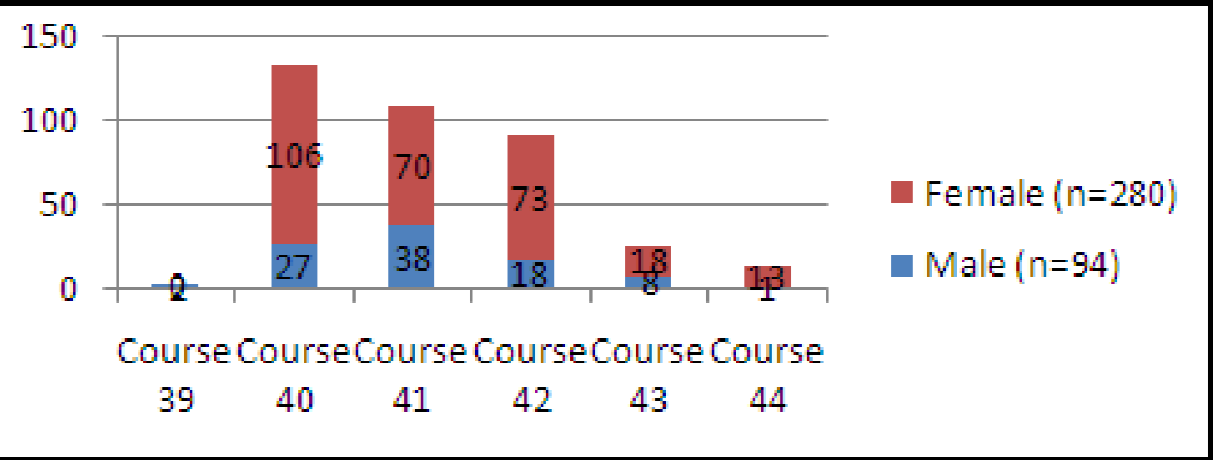

Figure 1: Student Volunteers by Gender

In comparison with the total number of current university students $(n=37,000)$, the ratio of volunteers at the library is only $1 \%$. In the meanwhile, the ratio of each school and college is a little bit higher such as College of Economics (1.7\%), College of Agriculture (2.1\%) and School of Social Sciences and Humanities (5.6\%) (Table 1).

\begin{tabular}{|c|c|c|c|c|}
\hline No & Name & Students & Volunteers & Ratio \% \\
\hline 1 & Can Tho University & 37,000 & 374 & 1 \\
\hline 2 & College of Economics & 4,195 & 73 & 1.7 \\
\hline 3 & College of Agriculture & 3,421 & 73 & 2.1 \\
\hline 4 & School of Foreign Languages & 1,057 & 26 & 2.5 \\
\hline 5 & School of Social Sciences and Humanities & 1,157 & 65 & 5.6 \\
\hline 6 & Library and Information Management Department & 278 & 58 & 20.9 \\
\hline
\end{tabular}

Table 1: Ratio of Student Volunteers at the LRC

Source: Can Tho University website

(https:/ / dap.ctu.edu.vn/ so-lieu-thon/ 55-so-lieu-thong-ke-quy-22019.html)

\subsection{Librarianship Volunteers}

Among 65 volunteers from School of Social Sciences and Humanities, nearly 90 percent of them are Librarianship students (89.2\%; $n=58)$. Librarianship volunteers are marked from Course 40 to Course 43 as 32, six, 18 and two students respectively (Figure 2). Definitely, most of them are from Course 40 and there is no librarianship volunteer in Course 44. Librarianship students are those who should be volunteers at the library to gain professional knowledge and skills for their future jobs. However, their participation is not as much as expected even though the current ratio of librarianship volunteers is high (20.9\%) compared to that of the university in general and of the School of Social Sciences and Humanities in particular (Table 1).

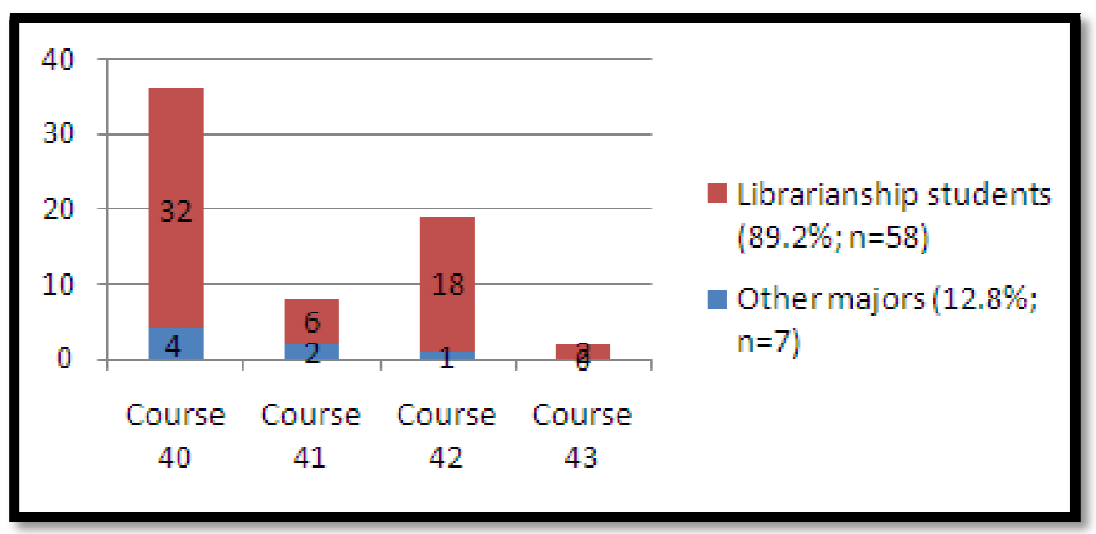

Figure 2: Librarianship Volunteers

4.3. Impacting Factors on Volunteering at the LRC

To explore the factors affecting the volunteering, the study usesExploratory Factor Analysis (EFA) in SPSS. EFA analysis is a statistical method used to shrink and reduce data. It is often aimed at simplifying an initial set of complex variables into a set of smaller variables in the form of factors(Hair et al, 2009). In this study, five groups of factors (Figure 3 ) with 44 observed variables are included in the survey to find the groups of factors that affect students' decisions to be volunteers. The minimum number of observed variables for each group of factors is 7 and maximum is 14 . 


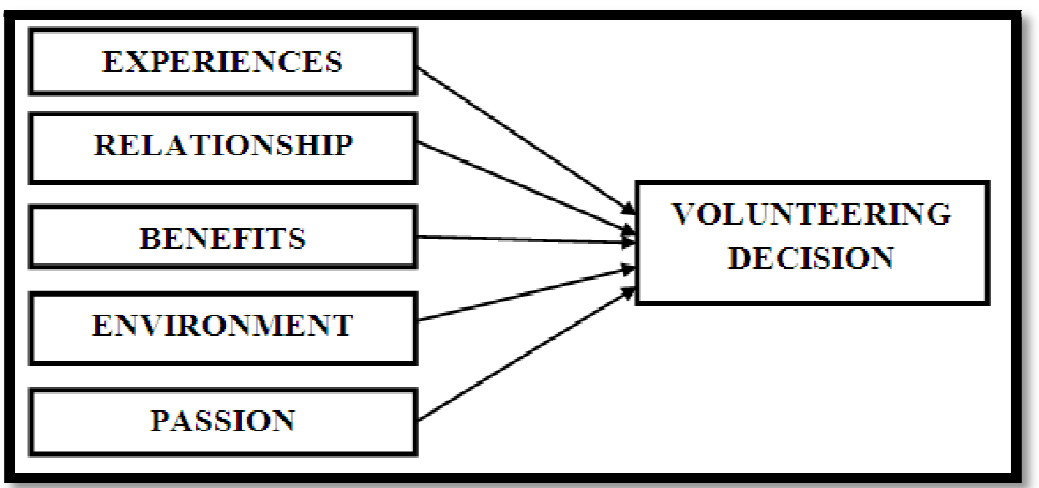

Figure 3: Model of Impacting Factors

Testing coefficient Cronbach's Alpha of each observed groups is a requirement in the EFA. Results of reliability test by coefficient Cronbach's Alpha (Table 2) show that the average Cronbach's Alpha is .855 and each single one is $>0.6$ (Hoang \& Chu, 2008). Thus, all 44 observed variables were eligible to be included in the analysis of the EFA.

\begin{tabular}{|c|c|c|c|c|}
\hline No & Observed groups of factors & Coded & Variables & Cronbach's Alpha \\
\hline 1 & Experiences & EX & 7 & 0.813 \\
\hline 2 & Relationships & RE & 8 & 0.847 \\
\hline 3 & Benefits & BE & 14 & 0.903 \\
\hline 4 & Environment & EN & 8 & 0.854 \\
\hline 5 & Passion & PA & 7 & 0.858 \\
\hline \multicolumn{2}{|c|}{ Average } & 44 & 0.855 \\
\hline
\end{tabular}

Table 2: Coefficient Cronbach's Alpha

In terms of conditions for implementing EFA, the number of observed variables in the five factor groups in Figure 3 and Table 2 are greater than 3, which satisfies the EFA requirements (Stevens 2002, Field 2000, Habing 2003). In addition, the number of samples is 100, which also meets the minimum requirement of 50 and 100 ideal observations by Hair and his colleagues(2009). Furthermore, with Bartlett and KMO Verification, the results of EFA analysis (Principal components with Varimax rotation) showed that KMO (Kaiser - Meyer - Olkin measure of sampling adequacy) $=0.783$ satisfies $0.5 \leq \mathrm{KMO} \leq 1$ to implement EFA and factor analysis relevant to research data.

\begin{tabular}{|c|c|c|}
\hline \multicolumn{3}{|c|}{ KMO and Bartlett's Test } \\
\hline \multicolumn{2}{|c|}{ Kaiser-Meyer-Olkin Measure of Sampling Adequacy. } & .783 \\
\hline \multirow{3}{*}{$\begin{array}{l}\text { Bartlett's Test of } \\
\text { Sphericity }\end{array}$} & Approx. Chi-Square & 2423.317 \\
\hline & $\mathrm{df}$ & 666 \\
\hline & Sig. & .000 \\
\hline
\end{tabular}

Table 3: KMO and Bartlett's Test

Data in Table 3 show that KMO $=0.783>0.70$ should be at the allowable level of EFA (Kaiser 1974). Bartlett's test results are 2423.317 with the observed variables in the overall correlated with each other with significance sig. $=0.000<$ 0.05. This proves that the data used for factor analysis is perfectly appropriate. There are five factors extracted at the stop eigenvalues of 1.086 and the extracting variance is $74.044 \%>50 \%$. The loading factor of all variables is $>0.783$ and the research has reached the ideal sample size 100 (Hair et al. 2009).

The results of EFA exploratory factor analysis with rotation matrix ( 02 times) show that there are five factors that affect the volunteer work of CTU students (Table 4). In which the first factor is the experience (EX) with six influential variables (library professional, management, event organization, technical skills, and conflict solving). The second influencing factor is the relationship (RE) with eight influential variables (librarians, library readers, off-campus readers, other volunteers, foreigners, businessmen, leaders and sponsors). The third influential factor is the benefit (BE) of ten influential variables (library hours, confident in communication, public speaking skills, teamwork skills, leadership skills, knowledge of religions, ability, being trusted, future goals, and employment opportunities. The fourth influential factor is the environment (EN) with six influential variables (academic environment, healthy place, safeplace, rich resources, friendly librarians, friendship, love). The fifth influence factor is the passion(PA) with nine influential variables (using time for good purpose, love for books, working with people, exploring the library, learning equipment and tools, ICT in the library, applying and sharing knowledge, practical knowledge, and exploring information resources). Thus, of the 44 observed variables, 39 variables affect student volunteers. 


\begin{tabular}{|c|c|c|c|c|c|}
\hline & \multicolumn{5}{|c|}{ Component } \\
\hline & 1 & 2 & 3 & 4 & 5 \\
\hline EN2 & .847 & & & & \\
\hline EN6 & .765 & & & & \\
\hline EN4 & .694 & & & & \\
\hline EN1 & 663 & & & & \\
\hline EN5 & .642 & & & & \\
\hline EN3 & 631 & & & & \\
\hline BE14 & & .800 & & & \\
\hline BE13 & & .789 & & & \\
\hline BE3 & & .789 & & & \\
\hline BE2 & & .776 & & & \\
\hline BE12 & & .758 & & & \\
\hline BE1 & & .717 & & & \\
\hline BE7 & & .683 & & & \\
\hline BE4 & & .675 & & & \\
\hline BE6 & & .635 & & & \\
\hline BE5 & & .597 & & & \\
\hline PA7 & & & .811 & & \\
\hline PA6 & & & .776 & & \\
\hline PA5 & & & .666 & & \\
\hline PA1 & & & .624 & & \\
\hline PA4 & & & .555 & & \\
\hline PA3 & & & .555 & & \\
\hline PA2 & & & .518 & & \\
\hline EX5 & & & & .816 & \\
\hline EX4 & & & & .787 & \\
\hline EX1 & & & & .780 & \\
\hline EX6 & & & & .778 & \\
\hline EX2 & & & & .667 & \\
\hline EX3 & & & & .601 & \\
\hline RE8 & & & & & .800 \\
\hline RE2 & & & & & .753 \\
\hline RE4 & & & & & .742 \\
\hline RE6 & & & & & .730 \\
\hline RE7 & & & & & .723 \\
\hline RE3 & & & & & .656 \\
\hline RE5 & & & & & .645 \\
\hline RE1 & & & & & .594 \\
\hline
\end{tabular}

Table 4: Rotated Component Matrix ${ }^{a}$

Extraction Method: Principal Component Analysis

Rotation Method: Varimax with Kaiser Normalization

In order to determine the influence level of factors on student volunteers, multivariate regression analysis should be carried out. Multivariate regression method is a method of estimating a single regression model with one or more independent variables. When the regression model consists of many dependent variables, the method of estimating this model is called Multivariate Multiple regression (Hair et al. 2009). In other words, multivariate regression analysis is a feature of SPSS that helps identify factors that contribute a lot / little / not to the change of independent variables.

\begin{tabular}{|c|c|c|c|c|}
\hline Model & $\mathbf{R}$ & R Square & Adjusted R Square & $\begin{array}{c}\text { Std. Error of the } \\
\text { Estimate }\end{array}$ \\
\hline 1 & $.728^{\mathrm{a}}$ & .530 & .505 & .49352 \\
\hline
\end{tabular}

Table 5: Model Summary

Data in Table 5, the coefficient of determination of $\mathrm{R} 2$ is 0.530 , indicating the relationship between the factors quite closely. At the same time, the coefficient $\mathrm{R} 2_{\text {adj }}$ is $0.505<\mathrm{R} 2$ showed that the independent variable did not explain further for the dependent variable (Nguyen 2012) and more than 50\% of the variance of the decision to volunteer at the library was explained by 5 independent variables: EX, RE, BE, EN, and PA. 


\begin{tabular}{|c|c|c|c|c|c|c|c|c|}
\hline \multicolumn{9}{|c|}{ Coefficients $^{a}$} \\
\hline \multirow{2}{*}{\multicolumn{2}{|c|}{ Model }} & \multicolumn{2}{|c|}{$\begin{array}{l}\text { Unstandardized } \\
\text { Coefficients }\end{array}$} & \multirow{2}{*}{$\begin{array}{c}\text { Standardized } \\
\text { Coefficients }\end{array}$} & \multirow[t]{2}{*}{$\mathrm{t}$} & \multirow[t]{2}{*}{ Sig. } & \multicolumn{2}{|c|}{ Collinearity Statistics } \\
\hline & & $\mathrm{B}$ & Std. Error & & & & Tolerance & VIF \\
\hline 1 & $\begin{array}{c}\text { (Constant } \\
\text { ) }\end{array}$ & .044 & .458 & & .097 & .923 & & \\
\hline & $\mathrm{EX}$ & -.062 & .106 & -.049 & -.581 & .563 & .713 & 1.403 \\
\hline & $\mathrm{RE}$ & .198 & .119 & .152 & 1.669 & .098 & .602 & 1.660 \\
\hline & $\mathrm{BE}$ & .103 & .139 & .080 & .741 & .460 & .434 & 2.305 \\
\hline & EN & .618 & .135 & .483 & 4.587 & .000 & .451 & 2.216 \\
\hline & PA & .240 & .133 & .185 & 1.802 & .075 & .476 & 2.100 \\
\hline
\end{tabular}

Table 6: Multivariate Multiple Regression

a. Dependent Variable: VO

According to the coefficient theory, VIF of which group of high-value factors will have the strongest influence on student volunteers. To determine this, phenomenon of multicollinearity between independent variables should be considered. Data of Table 6 shows three independent variables (BE, EN, and PA) with multi-collinear signs. Multicollinearity is the phenomenon of independent variables in the linear interdependence model. According to Nguyen (2012), the signs to identify multicollinearity are: If the magnification coefficient variance VIF (variance inflation factor) $>$ 2 , there are signs of multicollinearity, this is undesirable. If VIF $>10$ is sure to have multicollinearity. If $\mathrm{VIF}<2$ : not being multi-collinear. In addition, the acceptance value (Tolerance) is considered by the Tolerance $=1 /$ VIF formula. This coefficient is in the left column of the VIF coefficient. If the Tolerance coefficient is less than 0.5, there are signs of multicollinearity, this is undesirable. If the value of Tolerance is less than 0.1, then there is definitely a multicollinearity. According to the Multivariate Multiple Regression of Table 6, it is clearly that relationship (RE) is the most powerful and unique group of factors ( $\mathrm{VIF}=1.660$ ) to the student volunteers. The second most influential group is experience $(\mathrm{EX})$ with VIF of 1.403. The impacting levels of the remaining groups of factors could not be determined because of the multicollinearity phenomenon. This means that there are certain influences among other groups of factors, so it is impossible to identify their influence on the independent variable (the decision to volunteer at the library).

\subsection{Impacting Factors of Relationships}

Multivariate Multiple Regressionshown in Table 6 illustrates that the group of factors on relationships has the strongest influence on the students' decision to volunteer at the library. Research findings show that students are interested and want to expand the relationships with librarians, library readers, other volunteers, leaders, and sponsors (Table 7). It can be seen that the most interested factor on relationships is making relationships with other volunteers (RE4) with 42 students agree (42.0\%) and 35 students are completely agreeable (35.0\% ). The second interested factor on relationships is the relationship with the foreingers(RE5) with $43.0 \%$ students' agreement $(n=43)$. Other relationships with librarians (RE1), library readers (RE2), leaders (RE7), and sponsors (RE8) score at 35 (35.0\%), 37 (37.0\%), 33 $(33.0 \%)$ and $35(35.0 \%)$ respectively. Meanwhile, there was one volunteer who totally disagreed $(1.0 \%)$ of volunteering to expand the relationship with sponsors (RE8). Similarly, there were two students who completely disagreed $(2.0 \%)$ to volunteer due tothe relationship swith businessmen (RE6). These proved that students are more interested in expanding relationships with librarians, library readers, other volunteers, foreigners, leaders and sponsors rather than off-campus readers and businessmen. These research findings are similar to previous research that individuals volunteer to expand their personal and social relationships (Mario, 2016; Roberts, 2016; Shye, 2010).

\begin{tabular}{|c|c|c|c|c|c|c|c|c|c|c|c|}
\hline No & Factors & $\begin{array}{l}\text { Totally } \\
\text { disagre } \\
\text { ed }\end{array}$ & \multicolumn{2}{|c|}{$\begin{array}{l}\text { Disagree } \\
\text { d }\end{array}$} & \multicolumn{2}{|c|}{ Neutral } & \multicolumn{2}{|c|}{ Agreed } & \multicolumn{2}{c|}{$\begin{array}{c}\text { Totally } \\
\text { Agreed }\end{array}$} \\
\cline { 3 - 13 } & & $\mathbf{n}$ & $\mathbf{\%}$ & $\mathbf{n}$ & $\mathbf{\%}$ & $\mathbf{n}$ & $\mathbf{\%}$ & $\mathbf{n}$ & $\mathbf{\%}$ & $\mathbf{n}$ & $\mathbf{\%}$ \\
\hline 1 & Librarians (RE1) & 0 & 0 & 3 & 3.0 & 51 & 51.0 & 35 & 35.0 & 11 & 11.0 \\
\hline 2 & Library readers (RE2) & 0 & 0 & 2 & 2.0 & 43 & 43.0 & 37 & 37.0 & 18 & 18.0 \\
\hline 3 & $\begin{array}{c}\text { Off-campus readers } \\
\text { (RE3) }\end{array}$ & 0 & 0 & 7 & 7.0 & 60 & 60.0 & 22 & 22.0 & 11 & 11.0 \\
\hline 4 & Other volunteers (RE4) & 0 & 0 & 2 & 2.0 & 21 & 21.0 & 42 & 42.0 & 35 & 35.0 \\
\hline 5 & Foreigners (RE5) & 0 & 0 & 3 & 3.0 & 46 & 46.0 & 43 & 43.0 & 8 & 8.0 \\
\hline 6 & Businessmen (RE6) & 2 & 2.0 & 15 & 15.0 & 63 & 63.0 & 17 & 17.0 & 3 & 3.0 \\
\hline 7 & Leaders (RE7) & 0 & 0 & 8 & 8.0 & 41 & 41.0 & 33 & 33.0 & 18 & 18.0 \\
\hline 8 & Sponsors (RE8) & 1 & 1.0 & 7 & 7.0 & 47 & 47.0 & 35 & 35.0 & 10 & 10.0 \\
\hline
\end{tabular}

Table 7: Expansion of Relationships

\subsection{Impacting Factors of Experiences}

The second group of factors influencing on student volunteers is the experiences with six factors. Experiences that volunteers want to accumulate in volunteering at the library are displayed in Table 8. It can be seen that library professional (EX1), event organizing (EX3) and conflict solving (EX5) all have onestudent with totally disagreed answer 
(1.0\%). Most of experiences that can be accumulated in volunteering at the library are highly agreed. In particular,technical skills (EX4) has the highest level of consent, with $56 \%(n=56)$ and the second highest experience is proper solutions (EX6) with 51 agreed answers $(n=51)$. There were 19 volunteers who completely agreed $(19.0 \%)$ with volunteering to accumulate experience in conflict solving (EX5). In general, students want to learn the experience of professional library, leadership, event organizing, technical skills, conflict solving and proper solutions. These research findings are supporting the previous research that volunteers are willing to be helpers in order to gain professional experiences and skills (Bernier, 2009; Holdsworth, 2010; Mario, 2016).

\begin{tabular}{|c|l|c|c|c|c|c|c|c|c|c|c|}
\hline No & \multirow{2}{*}{ Factors } & $\begin{array}{c}\text { Totally } \\
\text { disagreed }\end{array}$ & \multicolumn{2}{c|}{ Disagreed } & \multicolumn{2}{c|}{ Neutral } & \multicolumn{2}{c|}{ Agreed } & \multicolumn{2}{c|}{$\begin{array}{c}\text { Totally } \\
\text { agreed }\end{array}$} \\
\cline { 3 - 13 } & & $\mathbf{n}$ & $\mathbf{\%}$ & $\mathbf{n}$ & $\mathbf{\%}$ & $\mathbf{n}$ & $\mathbf{\%}$ & $\mathbf{n}$ & $\mathbf{\%}$ & $\mathbf{n}$ & $\mathbf{\%}$ \\
\hline 1 & Library professional (EX1) & 1 & 1.0 & 05 & 5.0 & 46 & 46.0 & 30 & 30.0 & 18 & 18.0 \\
\hline 2 & Leadership (EX2) & 0 & 0 & 06 & 6.0 & 36 & 36.0 & 46 & 46.0 & 12 & 12.0 \\
\hline 3 & Event organising (EX3) & 1 & 1.0 & 03 & 3.0 & 40 & 40.0 & 44 & 44.0 & 12 & 12.0 \\
\hline 4 & Technical Skills (EX4) & 0 & 0 & 04 & 4.0 & 28 & 28.0 & 56 & 56.0 & 12 & 12.0 \\
\hline 5 & Conflict solving (EX5) & 1 & 1.0 & 07 & 7.0 & 40 & 40.0 & 33 & 33.0 & 19 & 19.0 \\
\hline 6 & Proper solutions (EX6) & 0 & 0 & 04 & 4.0 & 29 & 29.0 & 51 & 51.0 & 16 & 16.0 \\
\hline
\end{tabular}

Table 8: Gathering of Experiences

The study has identified five groups of factors affecting students' volunteering as experiences, relationships, benefits, environment and passion. The multivariate regression analysis finds out the two most influential factors in volunteering are relationships and experiences with the number of influencing factors, eight and six respectively. These factors are important because they help LRC to have a reference source to find out the ways to attract more and more students to participate in volunteering at the library.

\subsection{Suggestions to Attract More Student Volunteers}

Research findings ontwo groups of impacting factors (including experiences and relationships) are necessary to figure out detailed solutions to attract students in volunteering. In terms of relationships, the LRC needs to create more chances for volunteers to communicate and meet with LRC staff, library readers, foreigners, sponsors and leaders. This suggestion is similar toBernier's (2009) and Vi's (2017)and that volunteersshould have the opportunities to expand personal relationships. In related to gaining experiences,the LRC should organise extracurricular activities such as conversations, competitions, and workshops to help volunteers gain knowledge of library professional,leadership, event organizing technical skills, conflict solving and proper solutions. In addition, the LRC should pay attention to marketing methods to disseminate the need for volunteers at the library. The LRC should send emails to all students of the university, notification to every school and college, inform to new students in the orientation day, post volunteering needs on the LRC facebook and other social networking sites. Moreover, in the announcement of recruitment of volunteers, it is necessary to introduce the suitable environment at LRC for students, and point out responsibility, benefits, professional knowledge as well as social knowledge that students can obtain in volunteering.

It is recommended that the LRC should organize meetings for volunteers at least once a month to share difficulties and experiences as well as expand relationships among volunteers. Volunteers are encouraged to take turn to prepare for the contents of the meeting that makes them more creative. If this is done, volunteers can enhance theirskills practicesuch as teamwork, event organizing, and managing meeting time. These will encourage more students participating in volunteering activities at the library.

The LRCneeds to provide a variety of documents and modern equipment for the users. In using the equipment and software, it is difficult to avoid unexpected things. This requires the user andparticularlyvolunteers to know how to deal with. For example, when electricity is out, computer userswill lose their data and even tempers. At this time, volunteers can help them to calm down by usingappropriate instructions. Volunteers can contact the LRC staff to fix the problem quickly. Volunteers will have the opportunity to accumulate more problem solving experiences, ability to respond to incidents and provide appropriate solutions according to each case. Moreover,they have the opportunity to communicate with LRC staff to meet the needs of users,improve their knowledge as well as soft skills, and expand relationships.

Importantly, priority is given to librarianship students who are to work at the reference desk, audio-visual room, newspaper and magazine section, mobile library, and creative corner to gain library professional skills and knowledge. The LRC should organize regular training courses on information literacy with twenty students in each class and allow librarianship volunteers to involve in such service. Through these courses, librarianship volunteers can enhancemore experience of how to find information fromdatabases, figure out what databases are suitable for each specific discipline, and know how to use Zotero citation software.These experiences on the spot at the reference desk canhelp the users find information and documents for their own needs. During the orientation session, volunteers can talk and share their ideas with library readers and librarians to form the relationships among library staff, readers and volunteers.In addition, the LRC is encouraged toallow librarianship volunteers to participate in materials restoration, classification and technical processing of documents. 


\section{Conclusions}

Finding jobs has become a great concern for students after graduation. It is volunteering at the librarythat increases job opportunities and promotes their professionals. Being volunteers at the LRC, students have opportunities to interact, communicate directly with businessmen and recruiters. Therefore, volunteers will know the employers' requirements and get ready for their future jobs. In addition, they can practice teamwork skills, communication skills, expand their friendships and social relations, enrich their knowledge needed and relevant tofuture careers, create more fun and take responsibility for their own lives and studies. Furthermore, the more resilient to difficulties in life theyare, the better or greater experience in handling situations they gain, and more importantly, the more socially accountable they become.As experiences and relationships are two factors influencing volunteering, the LRC of Can Tho University need tofocus on marketing strategies to attract more volunteer students and pay attention to expandinggood volunteer programsat the library in terms of sustainability development.

\section{References}

i. AmeriCorps and Senior Corps. (2019). Serve in our community. Available at https:/ / www.nationalservice.gov/ serve.

ii. Ba Ria - Vung Tau University.(2017). Ke hoach tuyen tinh nguyen vien ho tro cac hoat dong tai Thu vien [Library volunteer recruitment plan]. Available at http:/ / sinhvien.bvu.edu.vn/ Resource/ Upload/ file/ LMLoi/ Thong\%20bao/ 10-2017/ kh526.pdf [20/ 9/ 2019].

iii. Bernier, A. (2009). Young adult volunteering in public libraries.Library Leadership \& Management, 23(3), 133-139.

iv. Berroteran, J. (2016). More meaningful recognition, support and appreciation of volunteers, In C. Smallwood, L. Sanborn, eds.Library volunteers welcome! Strategies for attracting, retaining and making the most of willing helpers(pp. 5-11).Jefferson, North Carolina, USA: McFarland \& Company, Inc.

v. Center for Counselling, Research and empowering community. (2016). Tuyen tinh nguyen vien du an Thu vien Ba tach tra [Volunteering recruitment for Three Cups of Tea Library project]. Available at http:/ / corecommunity.vn/ 2016/ 03/ tuyen-tinh-nguyen-vien-du-an-thu-vien-ba-tach-tra-32016/ ?lang=vi [18/ 6/ 2019].

vi. Clary, G. E., Snyder, M. and Ridge, R. (1992). Volunteers' motivations: A functional strategy for the recruitment, placement and retention of volunteers.Non-profit Management and Leadership, 2,333-350.

vii. Colibaba, A., Skinner, M. W. and Furgal, C. (2019). The challenges and opportunities of sustaining volunteer-based rural libraries.Public Library Quarterly, 1-18.

viii. Elery, D. (2002). The impact of volunteering experience on citizenship qualities in students: Perceptions and reflections of volunteering. Available at https:// www.aare.edu.au/data/ publications/2002/ ele02336.pdf $[17 / 6 / 2019]$.

ix. Do, T. B. T. (2016). Nhom tinh nguyen vien thu vien [Volunteering group at the library].Available at http:/ / lib.agu.edu.vn/ tin-tuc-va-su-kien/ hoat-dong/ 3054-nhom-tinh-nguyen-vien-thu-vien [20/ 9/ 2019].

x. Fairfield County District Library. Jobs/Volunteers. Available at https:// www.fcdlibrary.org/ contact/ jobsvolunteer/ [17/8/ 2019].

xi. Farlex. (2019). Free online dictionary, Farlex, Inc. Available at https://www.thefreedictionary.com/volunteer [18/ 6/ 2019].

xii. Field, A. (2000).Discovering Statistics using SPSS for Windows.London: Sage publications.

xiii. Forrest, M. (2012). Student volunteers in academic libraries.New Review of Academic Librarianship, 18, 1: 1-6.

xiv. Ha Linh. (2017). Chang trai 9X me tinh nguyen [9X guy in passion of volunteering]. Economy \& Town. Available at http:/ / m.kinhtedothi.vn/ chang-trai-9x-me-tinh-nguyen-286428.html [15/ 6/ 2019].

xv. Ha Vi. (2017). Tham gia tinh nguyen trong thoi dai hoc co loi ich gi?[What kind of benefits that student volunteers can get?]. Available at http://m.tiin.vn/ chuyen-muc/hoc/tham-gia-tinh-nguyen-trong-thoi-dai-hoc-co-loi-ichgi.html [18/ 7/2019].

xvi. Habing, B. (2003). Exploratory factor analysis. University of South Carolina. Available at http:/ / people.stat.sc.edu/ habing/ courses/ 530EFA.pdf [16/ 8/ 2019].

xvii. Hair, J. F., Black, W. C., Babin, B. J. and Anderson, R. E. (2009).Multivariate data analysis.Englewood Cliffs: Prentice Hall International.

xviii. Hall, M., Lasby, D., Ayer, S. and Gibbons, W. (2009).Caring Canadians, involved Canadians: Highlights from the 2007 Canada survey of giving, volunteering and participating.Ottawa, Canada: Minister of Industry.

xix. Hardill, I. and Baines, S. (2007). Volunteering for all? Explaining patterns of volunteering and identifying strategies to promote it.Policy \& Politics, 35(3), 395.

xx. Hoang Lam.(2012). Co gai "sinh ra de lam tinh nguyen" ["Born to be volunteer" girl], Dan Tri International. Available at https:// dantri.com.vn/ nhip-song-tre/ co-gai-sinh-ra-de-lam-tinh-nguyen-1352663264.htm [15/6/2019].

xxi. Hoang, T. and Chu, N. M. N. (2008).Phan tich du lieu nghien cuu voi SPSS [Analysing Data Using SPSS].Ho Chi Minh City, Vietnam: Hong Duc.

xxii. Hoang, T. P. (2016). Tinh nguyen trong toi la ... [Volunteering means...]. Available at http:/ / khoakinhte.vinhuni.edu.vn/ thong-bao/ seo/ tinh-nguyen-trong-toi-la-66912[15/ 6/ 2019].

xxiii. Holdsworth, C. (2010). Why volunteer? Understanding motivations for student volunteering.British Journal of Educational Studies, 58(4), 421-437. 
xxiv. Holdsworth, C. and Brewis, G. (2014). Volunteering choice and control: A case study of higher education student volunteering.Journal of Youth Studies, 17(2), 204-219.

xxv. Holt, L. E. and Holt, G. E. (2014).Success with library volunteers.Santa Barbara, California: Libraries Unlimited.

xxvi. Kaiser, H. (1974). An index of factor simplicity.Psychometrika, 39, 31-36.

xxvii. Learning Resource Center - LRC. (2018). Tinh nguyen vien [Volunteers]. Available at http:/ / www.lrc.ctu.edu.vn/ tinh-nguyen-vien/ data-articles/ tin-tuc/ muon-tra-tai-lieu [18/ 7/ 2019]

xxviii. Lehn, C. C. (2016). Finding and keeping good volunteers: From recruitment to sustainability, In C. Smallwood, L. Sanborn, eds.Library volunteers welcome! Strategies for attracting, retaining and making the most of willing helpers(pp.33-41).North Carolina, USA: Mcfarland \& Company, Inc., Jefferson.

xxix. Mario, P. (2016). Du an thu vien xanh tuyen tinh nguyen vien 2016 [Green Library project recruits volunteers 2016]. Available at https://ybox.vn/ tinh-nguyen/du-an-thu-vien-xanh-tuyen-tinh-nguyen-vien-2016-290087 [16/ 7/ 2019].

xxx. McCabe, T. L., White, K. M. and Obst, P. L. (2007). The importance of volunteering functions to university students.Australian Journal of Volunteering, 12(2), 50-58.

xxxi. McDonald, D. (1996). By working together, we can keep excellent library service. Available at https:// searchproquest-com.dbonline.cesti.gov.vn/ docview/353172553?accountid=39958 [18/ 7/ 2019].

xxxii. Nguyen, D. T. (2012).Phuong phap nghien cuu khoa hoc trong kinh doanh [Scientific research methods in Business].Ha Noi, Vietnam: Lao dong Xa hoi.

xxxiii. Nguyen, Q. M. T. (2016). Lam tinh nguyen vien o Phap con vat va hon xin viec [Volunteering in France is more difficult than applying for job]. Available at https:/ / news.zing.vn/ lam-tinh-nguyen-vien-o-phap-con-vat-va-honxin-viec-post663149.html [15/ 6/ 2019].

xxxiv. Nguyen, T. D. (2013). Tinh nguyen vao thu vien ... xep sach [Volunteers re-shelve books at the library].Available at http:/ / giaoducthoidai.vn/ dia-phuong/ tinh-nguyen-vao-thu-vien-xep-sach-53813-u.html [17/ 8/ 2019].

xxxv. Public Library Association. (2019). Volunteer with PLA.Public Libraries, 58(2), 4.

xxxvi. Riemer, H. A., Dorsch, K. D., Paskevich, D. M. and Chelladurai, P. (2004). Motives for volunteering: Categorization of volunteers' motivations using open-ended questions. Knowledge Development Centre Canadian Centre for Philanthropy. Available at http:// www.imaginecanada.ca/ sites/ default/ files/ www/ en/ library/ kdccdc/ motivations for volunteering.pdf [16/7/2019].

xxxvii. Roberts, F. C. (2016). How to undermine your volunteer program: A dozen ways to fail, In C. Smallwood, L. Sanborn. Eds.Library volunteers welcome! Strategies for attracting, retaining and making the most of willing helpers(pp. 87-94).Jefferson, North Carolina, USA: McFarland \& Company, Inc.

xxxviii. San Antonio Public Library. Volunteer. Available at https://www.mysapl.org/ About/ How-toHelp/ Volunteer[16/ 7/ 2019].

xxxix. Seattle Public Library. (2018). Become a volunteer. Available at https://www.spl.org/about-us/ supportus/ volunteer[16/ 7/ 2019].

xl. Seattle Public Library. (2018). Volunteer opportunities for adults. Available at https://www.spl.org/aboutus/ support-us/ volunteer/ volunteer-opportunities-for-adults.

xli. Seattle Public Library. (2018). Volunteer opportunities for teens. Available at https://www.spl.org/aboutus/ support-us/ volunteer/ volunteer-opportunities-for-adults[16/ 7/ 2019].

xlii. Shye, S. (2010). The motivation to volunteer: A systemic quality of life theory.Social Indicators Research, 98 (2), 183-200.

xliii. Stevens, J. P. (2002).Applied multivariate statistics for the social sciences.Mahwah, NJ: Lawrence Erlbaum Associates.

xliv. Toronto Public Library. Volunteer programs. Available at https://www.torontopubliclibrary.ca/ supportus/ volunteering/ [16/ 7/ 2019].

xlv. University of Economics and Law Library. (2017). Thong bao tuyen tinh nguyen vien [Announcement to recruit volunteers]. Available at http:// lib.uel.edu.vn/ArticleId/ 7a3c5d15-56af-486c-914e-636449c0953f/ thong-baotuyen-tinh-nguyen-vien[16/ 7/2019].

xlvi. US Fed News Service. (2006). Become a volunteer library tutor. Available at https:// search-proquestcom.ezproxy.lib.rmit.edu.au/ docview/472233959?accountid=13552\&rfr id=info\%3Axri\%2Fsid\%3Aprimo[16/ 7/ 2019].

xlvii. US Fed News Service. (2009). Volunteer library project day. Available at https://search-proquestcom.ezproxy.lib.rmit.edu.au/ docview/470567575?accountid=13552\&rfr_id=info\%3Axri\%2Fsid\%3Aprimo[16/7/ 2019].

xlviii. Wilson, J. (2000). Volunteering.Annual Review of Sociology,26 (1),215-240. 